\title{
平衡・非平衡流砂モデルおよびDEMを用いた 堰下流部における局所洗掘解析の比較 NUMERICAL SIMULATION ON LOCAL SCOUR BELOW A WEIR USING EQUILIBRIUM, NON-EQUILIBRIUM MODELS AND DEM FOR SEDIMENT-TRANSPORT
}

\author{
梶川 勇樹 1 檜谷 治 2 \\ Yuki KAJIKAWA and Osamu HINOKIDANI \\ 1正会員 博(工) 鳥取大学大学院助教 工学研究科社会基盤工学専攻（率680-8552 鳥取市湖山町南4-101） \\ 2正会員 工博 鳥取大学大学院教授 工学研究科社会基盤工学専攻（率680-8552 鳥取市湖山町南4-101）
}

\begin{abstract}
In this study, numerical simulations using equilibrium, non-equilibrium models and DEM for sedimenttransport were performed for local scour below a weir. First, the coupling technique between the vertical 2D flow model introduced with the FAVOR method and DEM was explained. Next, comparisons with the previous sediment-transport formulas and the DEM model were carried out, and the validity of the DEM model was examined. Finally, simulations by each model were performed for initial local scour process below a weir. Consequently, the DEM model was able to reproduce the local scour process. Moreover, the development speed of the local scour by the non-equilibrium sediment-transport model was slow. Therefore, it was pointed out that the model is not suitable for prediction of this phenomenon.
\end{abstract}

Key Words : weir, local scour, equilibrium and non-equilibrium sediment transport, DEM, vertical $2 D$ flow, numerical simulation

\section{1. はじめに}

床固め工あるいは堰下流部で発生する局所洗掘現象は, 堰上で支配断面が形成されるような流れの場合，潜り噴 流流れと波状跳水流れとが交互に発生しながら洗掘が進 行する非常に複雑な現象となる ${ }^{1)}$. 特に, 潜り噴流時に は，堰上を剥離した主流水脈が河床面に衝突するように 流下するため，堰直下で急激な洗掘が生じる．このよう な局所洗掘現象は，構造物の安定性を低下させるのみな らず，周辺護岸等にも影響を及ぼすため，防災上非常に 重要な問題となる. そのため, 従来よりその洗掘機構の 解明, 洗掘深の予測に関して数多くの研究がなされてき た ${ }^{1)-5)}$. 近年では数值解析による研究が盛んに行われて おり, 内田ら苂著者ら5により，その洗掘現象および最 大洗掘深についてある程度の予測が可能となっている.

しかしながら, 数值解析による洗掘現象の再現に関し 幾つかの問題点も指摘されている. 内田ら ${ }^{4}$ は，平衡・ 非平衡流砂モデルによる解析を行っているが，解析結果 は実験に比べて局所洗掘の発達速度が非常に遅いことを 指摘している．これは，既存の流砂量式では，水吒き部 での激しい流体混合による土砂輸送能力の増大を考慮で
きないためとしている。また，著者ら5)は，実験におけ る潜り噴流時の激しい流砂の巻き上がり現象を表現する ため，浮遊砂を考慮した平衡流砂モデルによる解析を 行っている.しかし，解析では浮遊砂の発生は殆ど認め られず，流砂の巻き上り現象の再現には至っていない.

上記の問題に対し，本研究では個別要素法 (DEM) を

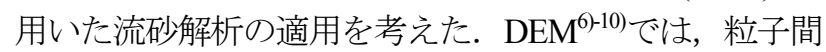
接触をバネとダッシュポット等でモデル化しており，現 象の物理的意味合いを厳密に表現しているわけではない. しかし，近年，DEMとオイラー的流体解析を連成させ た解析手法により，高濃度平衡流砂場への適用 ${ }^{8)}$ やDune 発生過程への適用等でその有効性が示されている. 局 所洗掘解析への適用は, Golparvar ${ }^{10)}$ が海洋パイプライ ン下の洗掘現象に適用し, 実験值との良好な一致を見せ ている. 従って，堰下流部で発生する局所洗掘現象への DEMの適用も十分期待でき，更に，DEMによる現象の 再現が可能となれば，解析による流砂の巻き上がり現象 の解明および流砂量式への言及も期待される.

以上より, 本研究では堰下流部で発生する局所洗掘現 象を対象とし，従来提案されている平衡・非平衡流砂モ デル ${ }^{11)}$ に加え，DEMによる局所洗掘解析を試みた。まず， DEMを用いた河床変動モデルを構築し, 既往流砂量式 
との比較から，モデルの妥当性について検討した．次に， 堰下流部の局所洗掘現象を対象とし，各流砂モデルによ る潜り噴流時の初期洗掘過程について検討を行った.

\section{2. 基礎方程式}

\section{（1）鉛直 2次元流れの基礎方程式}

本研究では座標系にデカルト座標系を採用し，時間的 に変動する自由水面および河床形状を適切に表現できる よう，FAVOR法5)を基礎式に導入した．乱流モデルには, 流砂の挙動を精度よく再現するため，高レイノルズ型2

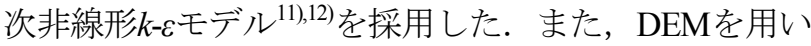
た河床変動解析では，流体中に存在する粒子群を，流体 に対して相対速度をもつ離散的粗度と捉え，清水ら ${ }^{8)}$ と 同様の表現により，流体場の基礎式に導入した。

[運動方程式 ]

$$
\begin{aligned}
\frac{\partial u_{i}}{\partial t} & +\frac{1}{V}\left\{\frac{\partial A_{(j)} u_{j} u_{i}}{\partial x_{j}}\right\}=-g \delta_{2 i}-\frac{1}{\rho} \frac{\partial P}{\partial x_{i}} \\
& +\frac{1}{V} \frac{\partial A_{(j)} \cdot-\overline{u_{i} u_{j}}}{\partial x_{j}}+\frac{1}{V} \frac{\partial}{\partial x_{j}}\left\{A_{(j)} \nu \frac{\partial u_{i}}{\partial x_{j}}\right\}-\frac{v_{g}}{\rho} F_{D i}
\end{aligned}
$$

[ 連続式 ]

$$
\frac{\partial}{\partial t}\left\{A_{(j)} u_{j}\right\}=0
$$

[ $k$-方程式 ]

$$
\begin{aligned}
\frac{\partial k}{\partial t}+\frac{1}{V}\left\{\frac{\partial A_{(j)} u_{j} k}{\partial x_{j}}\right\}= & \frac{1}{V} \frac{\partial}{\partial x_{j}}\left\{A_{(j)}\left(\frac{v_{t}}{\sigma_{k}}+v\right) \frac{\partial k}{\partial x_{j}}\right\} \\
& -\overline{u_{i} u_{j}} \frac{\partial u_{i}}{\partial x_{j}}-\varepsilon-P_{f}
\end{aligned}
$$

[ $\varepsilon-$ 方程式 ]

$$
\begin{array}{r}
\frac{\partial \varepsilon}{\partial t}+\frac{1}{V}\left\{\frac{\partial A_{(j)} u_{j} \varepsilon}{\partial x_{j}}\right\}=\frac{1}{V} \frac{\partial}{\partial x_{j}}\left\{A_{(j)}\left(\frac{v_{t}}{\sigma_{\varepsilon}}+v\right) \frac{\partial \varepsilon}{\partial x_{j}}\right\} \\
-C_{1 \varepsilon} \frac{\varepsilon}{k} \overline{u_{i} u_{j}} \frac{\partial u_{i}}{\partial x_{j}}-C_{2 \varepsilon} \frac{\varepsilon^{2}}{k}-C_{f} \frac{\varepsilon}{k} P_{f} \\
P_{f}=v_{g}\left(F_{D x} u+F_{D z} w\right), \quad C_{f}=1.3 C_{1 \varepsilon}
\end{array}
$$

ここに，t: 時間，添え字 $i, j$ : 総和規約に従い， $(1,2)$ は それぞれ $(x, z)$ 方向を表す， $u_{j}: j$ 方向の流速成分， $V$ : 体 積率, $A_{(j)}: j$ 方向の面積率, $g$ : 重力加速度, $\delta:$ ク口 ネッカーのデルタ, $\rho$ : 流体の密度, $P=p+2 / 3 \rho k, p$ : 圧 力, $-\overline{u_{i} u_{j}}$ : レイノルズ応力, $v$ : 動粘性係数, $k$ : 乱流工 ネルギー， $\varepsilon$ : 乱流エネルギー散逸率， $v_{t}$ : 渦動粘性係数, $F_{D i}: i$ 方向の粒子群反力, $v_{g}$ : 後述する粒子数密度であ る. 式(3)，(4)のモデル定数には， $\sigma_{k}=1.0 ， \sigma_{\varepsilon}=1.3 ， C_{1 \varepsilon}$ $=1.44 ， C_{2 \varepsilon}=1.92$ を用いた。 また，式(1)，(3)および(4)に おける右辺最終項は，DEMを用いた河床変動解析で導 入した項であり，平衡・非平衡流砂モデルによる河床変 動解析では導入していない.

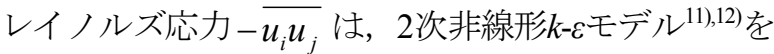
用いて，次のように評価した。

$$
\begin{gathered}
-\overline{u_{i} u_{j}}=v_{t} S_{i j}-\frac{2}{3} k \delta_{i j}-\frac{k}{\varepsilon} v_{t} \sum_{\beta=1}^{3} C_{\beta}\left(S_{\beta i j}-\frac{1}{3} S_{\beta \alpha \alpha} \delta_{i j}\right) \\
v_{t}=C_{\mu}\left(k^{2} / \varepsilon\right) \\
S_{i j}=\frac{\partial u_{i}}{\partial x_{j}}+\frac{\partial u_{j}}{\partial x_{i}}, \quad S_{1 i j}=\frac{\partial u_{i}}{\partial x_{r}} \frac{\partial u_{j}}{\partial x_{r}}, \\
S_{2 i j}=\frac{1}{2}\left(\frac{\partial u_{r}}{\partial x_{i}} \frac{\partial u_{j}}{\partial x_{r}}+\frac{\partial u_{r}}{\partial x_{j}} \frac{\partial u_{i}}{\partial x_{r}}\right), \quad S_{3 i j}=\frac{\partial u_{r}}{\partial x_{i}} \frac{\partial u_{r}}{\partial x_{j}}
\end{gathered}
$$

式(6)，(7)中のモデル係数は以下のように評価した.

$$
\begin{gathered}
C_{1}=\frac{0.4}{1+0.01 M^{2}}, \quad C_{2}=0.0, \quad C_{3}=\frac{-0.13}{1+0.01 M^{2}} \\
M=\max (S, \Omega) \\
S=\frac{k}{\varepsilon} \sqrt{\frac{1}{2}\left(\frac{\partial u_{i}}{\partial x_{j}}+\frac{\partial u_{j}}{\partial x_{i}}\right)^{2}}, \quad \Omega=\frac{k}{\varepsilon} \sqrt{\frac{1}{2}\left(\frac{\partial u_{i}}{\partial x_{j}}-\frac{\partial u_{j}}{\partial x_{i}}\right)^{2}} \\
C_{\mu}=\min \left\{0.09,0.3 /\left(1+0.09 M^{2}\right)\right\}
\end{gathered}
$$

\section{（2）非平衡流砂による河床変動の基礎方程式}

非平衡流砂による河床変動解析には次式を用いた.

$$
\frac{\partial z_{b}}{\partial t}=\frac{1}{1-\lambda} \frac{A_{3}}{A_{2}} d\left(p_{d}-p_{s}\right)
$$

ここに, $z_{b}$ : 河床位, $\lambda$ : 河床の空隙率 $(=0.4), A_{2}, A_{3}$ : 砂 粒の2次元, 3次元形状係数 $(=\pi / 4, \pi / 6), d$ : 河床材料粒径, $p_{s}:$ pick-up rate, $p_{d}:$ deposit rateである.

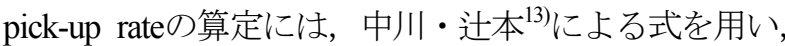
砂粒群の移動は砂粒の運動方程式を解かず， pick-up地点 の底面流速方向へ輸送されるものとした．また， deposit rateは, pick-upされた砂粒群がstep lengthの確率密度関数 に従って堆積するものとして計算した. ただし, deposit rate算定の際，ある地点での掃流力が限界掃流力以下と なった場合，その地点で砂粒群は停止すると考え， pickupされている残りの土砂量全てを堆積させた.

$$
\begin{gathered}
p_{s} \sqrt{\frac{d}{(\sigma / \rho-1) g}}=0.03 \tau_{*}\left(1-\frac{0.7 \Phi \tau_{* c}}{\tau_{*}}\right)^{3} \\
\Phi=\left(\mu_{s} \cos \theta_{b}-\sin \theta_{b} \cos \gamma\right) / \mu_{s} \\
f_{s}(s)=\frac{1}{\Lambda} \exp \left(-\frac{s}{\Lambda}\right)
\end{gathered}
$$

ここに, $\sigma$ : 砂粒の密度， $\tau_{*}$ : 無次元掃流力, $\tau_{*}$ ：無次元 限界掃流力, $\mu_{s}$ : 砂の静止摩擦係数 $(=0.7), \theta_{b}$ : 河床傾 斜角, $\gamma$ : 砂粒の移動方向と河床傾斜方向のな寸角, $f_{s}(s)$ : step lengthの確率密度関数, $s$ : 砂粒がpick-upされ た地点からの距離, $\Lambda$ : 平均step lengthである. 平均step lengthに関し，本研究では堰直下の流れ急変部を対象と することから，Einstein ${ }^{14)} の$ 式で評価した。

\section{（3）平衡流砂による河床変動の基礎方程式}

平衡流砂量 $q_{B}$ は，式(11)から得られる $p_{s}$ を用いて式(13) より求め, 式(14)により河床変動を計算した ${ }^{11)}$.

$$
\begin{gathered}
q_{B}=\frac{A_{3}}{A_{2}} p_{s} \Lambda d \\
\frac{\partial z_{b}}{\partial t}+\frac{1}{1-\lambda} \frac{\partial q_{B}}{\partial x}=0
\end{gathered}
$$




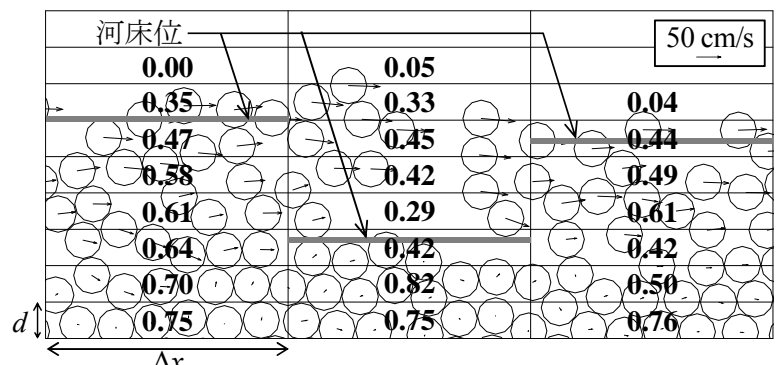

図-1 河床位の決定方法

\section{（4）DEMl基づく粒子の運動方程式}

$\mathrm{DEM}^{6-10)}$ では，個々の粒子間接触点において，法線お よび接線方向に弾性スプリング (バネ定数 $\left.k_{n}, k_{s}\right)$ および 粘性ダッシュポット（粘性定数 $\eta_{n}, \eta_{s}$ ) が導入され粒子間 相互作用力が計算される．鉛直2次元場における流水中 の砂粒子の並進および回転の運動方程式は次式で与えら れる.

$$
\begin{array}{r}
\rho\left(\frac{\sigma}{\rho}+C_{M}\right) A_{3} d^{3} \frac{d u_{p i}}{d t}=F_{p \text { int } i}+F_{D i} \\
-\rho\left(\frac{\sigma}{\rho}-1\right) A_{3} d^{3} g \delta_{2 i} \\
\sigma \frac{\pi d^{5}}{60} \frac{d \sigma_{p}}{d t}=\frac{d}{2} \cdot f_{p \text { int } s} \\
F_{D i}=\left[\begin{array}{l}
F_{D x} \\
F_{D z}
\end{array}\right]=\Xi_{F D}\left[\begin{array}{l}
u_{s}-u_{p} \\
w_{s}-w_{p}
\end{array}\right] \\
\Xi_{F D}=\frac{1}{2} \rho C_{D} A_{2} d^{2} \sqrt{\left(u_{s}-u_{p}\right)^{2}+\left(w_{s}-w_{p}\right)^{2}}
\end{array}
$$

ここに, $C_{M}$ : 付加質量係数 $(=0.5), u_{p i}: i$ 方向の粒子移動 速度成分, $F_{p \text { inti }}$ : スプリング・ダッシュポットシステム から評価される粒子間相互作用力成分, $\omega_{p}$ : 粒子の回転 速度, $f_{p \text { ints }}$ : 粒子間相互作用力の接線方向成分, $\left(u_{s}, w_{s}\right)$ : 後述するグリッド中央流速成分 $\left(u_{c}, w_{c}\right)$ から内挿により得 られる粒子に作用寸る流速成分, $C_{d}$ : 抗力係数である.

\section{DEMを用いた河床変動モデルの概要}

流れ場の計算手法については参考文献15)，平衡・非 平衡流砂による河床変動モデルについては, 基本的に参 考文献5)と同様であるため割愛し，ここでは，DEMを用 いた河床変動モデルについて説明する.

\section{（1）河床位の決定方法}

本研究では, 流体解析において基礎式にFAVOR法を 導入し，流体格子と物体（河床）形状を完全に独立して 定義している，そのため，流体格子を構築するには，D EMによって得られた個々の粒子位置より河床位を求め る必要がある．ここでは，その河床位の決定方法につい て説明する，まず，図-1に示すように，デカルト座標系 において，計算領域を鉛直方向に粒径dで均等に分割し， 各層内に存在する粒子が占める占有率を求める. 占有率 は層内中央点で定義する. 次に, 占有率がある閾值とな

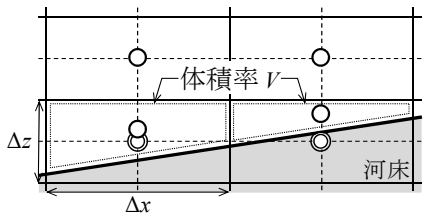

O : FAVOR法による流速定義点 $(u, w)$ ○：DEMにおける流速定義点 $\left(u_{c}, w_{c}\right)$ (a) FAVOR法

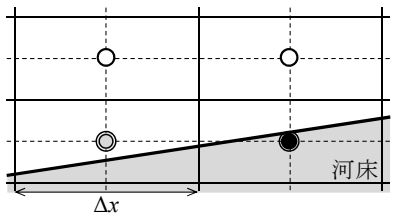

○：対数則より補間

○ : 流速值ゼロ

(b) DEMモデル

\section{図-2 流速定義位置}

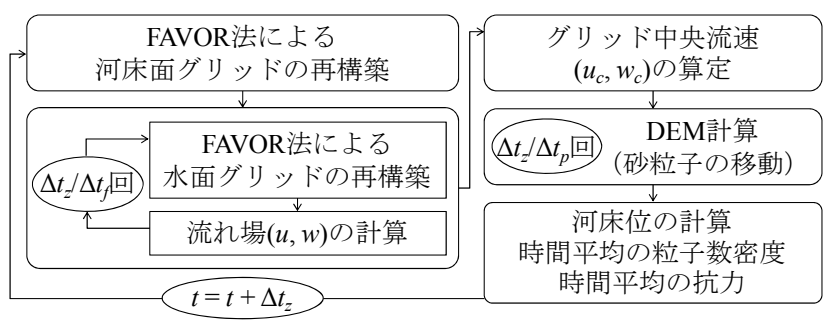

図-3ＤEM河床変動モデルのフローチャート

る高さを線形補間により求め, その位置を河床位と定義 した，闇值について，笠原ら 30\%以下) のグリッドを河床と定義しているが，本研究 では占有率 $40 \%$ (= 0.4)を閾值とした. これは，後藤ら と同様のモデルを用い，掃流力を変化させた計算を行っ た結果，流速がゼロとなる河床位での占有率が $20 \%$ 60\%であったため, 平均值として $40 \%(=0.40)$ を採用した。

ただし，掃流力が大きい場合，上記手法を用いてある 瞬間の粒子位置のみより河床位を求めると，図-1のよう に，河床位が凸凹に表現される場合がある，そこで，本 研究では河床変動の計算時間間隔 $\Delta t_{z}$ 間に $\Delta t_{z} / \Delta t_{p}$ 回 $\left(\Delta t_{z} 》\right.$ $\Delta t_{p}: \Delta t_{p}$ はDEM計算時間間隔) のDEM計算を行うが，そ の間に数回程度占有率を求め, その平均值を $\Delta t_{z}$ 後の占有 率とした. それにより, 安定した計算が可能となった。

\section{（2）粒子に作用する流速について}

本研究では，図-2(a)に示されるように，DEM計算に おいて個々の粒子に作用する抗力を求める際の流速 $\left(u_{c}\right.$, $w_{c}$ )をグリッド中央点で定義しており, 壁面境界近傍で は, 流体解析で用いているFAVOR法での流速定義点と 位置が異なる. そのため, 流体解析により得られた流速 值 $(u, w)$ から，グリッド中央点の流速值 $\left(u_{c}, w_{c}\right)$ を補間する 必要がある. ここでは，図-2(b)に示すように，グリッ ド中央点が河床位よりも上である場合，流体解析から得 られた底面近傍流速点以下では対数則が成り立つとし， グリッド中央流速を補間した。 また，グリッド中央点が 河床位以下である場合には，流速值をゼロとした．補間 された流速值 $\left(u_{c}, w_{c}\right)$ を用いて，個々の粒子位置における 流速 $\left(u_{s}, w_{s}\right)$ を距離に応じた重多付きにより内挿した.

\section{（3）既往流砂量式との比較}

以上の手法を用いて，既往流砂量式との比較を行った. 計算フローチャートを図-3に示す，計算は, 流下方向 20 $\mathrm{cm}$ の領域 $(\Delta x=1.0 \mathrm{~cm}, \Delta z=0.4 \mathrm{~cm})$ に対し, 粒径を変えて 


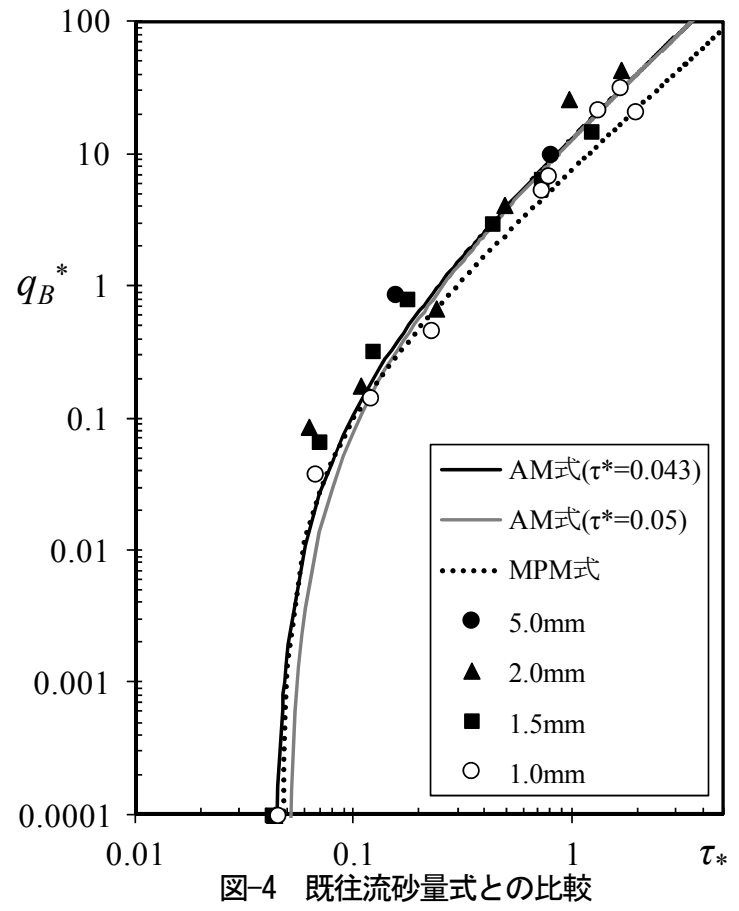

厚さ $2 \mathrm{~cm}$ 程度に落下法により砂を敷詰め，水深を $5 \mathrm{~cm}$ と 固定して流量を変化させた。側方境界では周期境界条件 とし，また，DEMの各種パラメータについては，後藤 $ら^{7}$ の手法により同定した。無次元流砂量 $q_{B}{ }^{*}$ については 次式より算定した6).

$$
\begin{gathered}
q_{B}^{*}=\left\{A_{3} d^{3} \int v_{g}(z) \cdot u_{p}(z) d z\right\} / \sqrt{(\sigma / \rho-1) g d^{3}} \\
v_{g}=\frac{\beta_{g}}{d \cdot \Delta x \cdot A_{2} d^{2}} \sum A_{s i}
\end{gathered}
$$

ここに, $\beta_{g}: 3$ 次元性の効果を表す補正係数 $(=0.82)$, $\sum A_{s i}$ : 検査面積 $(=d \Delta x)$ における粒子部分総面積である.

図-4は，芦田・道上式 (AM式) およびM.P.M式と計算 結果との比較を行ったものである、計算結果は，流砂が 定常状態に達した後の, 領域平均の流砂量を示している. 眓から分かるように，本数值モデルは既往流砂量式とほ ぼ一致していることが分かる.

\section{4. 堰下流部の局所洗掘解析}

従来，著者ら 5)が行った堰下流部の局所洗掘に関する 実験とほぼ同条件を対象に，初期洗掘について平衡・非 平衡流砂およびDEMによる河床変動解析を行った.

\section{（1）計算条件}

堰の設置状況を図-5に，計算条件を表-1にそれぞれ示 す。実験)では一様粒径 $d=0.75 \mathrm{~mm}$ を使用したが，ここで は計算メモリの制約上，比較的径の粗い $d=1.5 \mathrm{~mm}$ とした また，図-5では堰下流 $60 \mathrm{~cm}$ の領域に砂を敷詰めている が，これはDEMモデルの場合であり，平衡・非平衡流 砂モデルでは堰下流全域を移動床とした。 $\Delta t_{z}, \Delta t_{f}$ は全モ デルを通じて同様である，DEMパラメータについては，



図-5 堰設置状況

表-1 堰下流部の局所洗掘現象に関する計算条件

\begin{tabular}{c|c|cc|c}
\hline 堰高さ $W(\mathrm{~cm})$ & 5.0 & 河床変動時間ステップ $\Delta t_{z}(\mathrm{sec})$ & $2.0 \times 10^{-1}$ \\
\hline 単位幅流量 $q\left(\mathrm{~cm}^{2} / \mathrm{s}\right)$ & 267 & 流れ時間ステップ $\Delta t_{f}(\mathrm{sec})$ & $5.0 \times 10^{-4}$ \\
\hline 下流端水深 $h_{t}(\mathrm{~cm})$ & 8.52 & DEM時間ステップ $\Delta t_{p}(\mathrm{sec})$ & $4.0 \times 10^{-6}$ \\
\hline 河床勾配 $I$ & $1 / 300$ & 流下方向グリッド幅 $\Delta x(\mathrm{~cm})$ & 1.5 \\
\hline 粗度係数 $n$ & 0.014 & 鉛直方向グリッド幅 $\Delta z(\mathrm{~cm})$ & 0.4 \\
\hline 河床砂粒径 $d(\mathrm{~mm})$ & 1.5 & \multicolumn{3}{|c}{ 粒子数 } \\
\hline
\end{tabular}

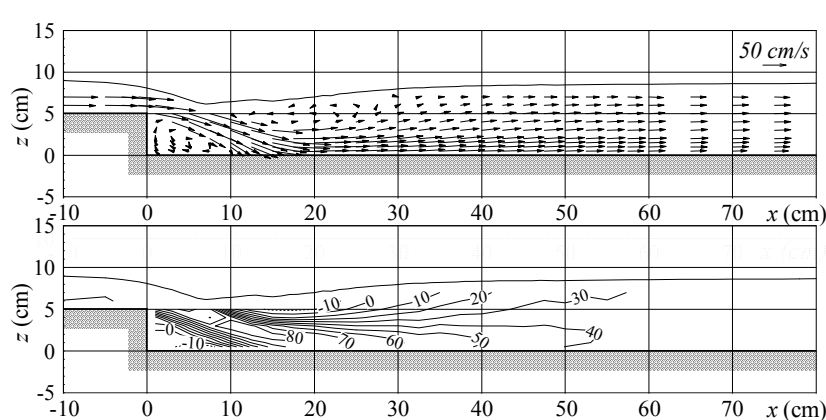

（a）実験結果（上 : 流速ベクトル図，下：等流速線図）

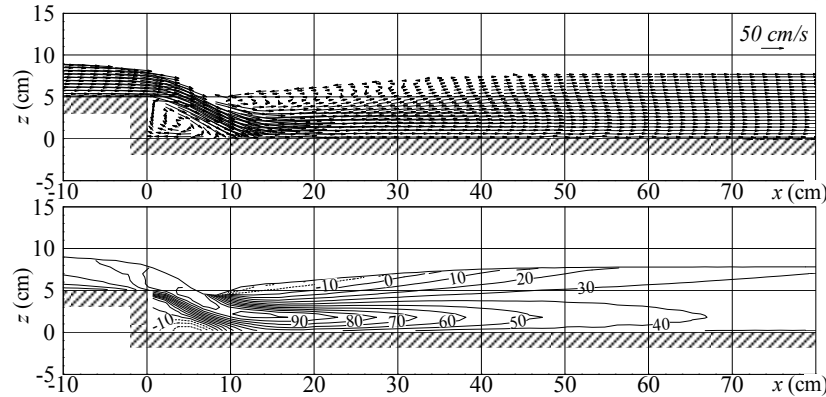

(b) 計算結果（上 : 流速ベクトル図, 下 : 等流速線図) 図-6＼cjkstart初期河床における流況の比較

$k_{n}=2.01 \times 10^{2}(\mathrm{~N} / \mathrm{m}), k_{s}=0.77 \times 10^{2}(\mathrm{~N} / \mathrm{m}), \eta_{n}=0.67 \times 10^{-1}$ $(\mathrm{Ns} / \mathrm{m}), \eta_{s}=0.41 \times 10^{-1}(\mathrm{Ns} / \mathrm{m})$ とした.

\section{（2）初期流況の比較}

図-6は，河床変動前の初期流況について比較したもの である．計算結果は，堰下流 $60 \mathrm{~cm} の$ 領域に落下法によ りパッキングした後の河床位を用いて計算したものであ る. 図より，計算結果は実験同様，潜り噴流流れの特徵 的な流況を良好に再現できていることが分かる．ただし， 堰下流域での主流速の減少が十分再現できていない。こ れは，潜り噴流時の3次元的な流況を鈆直2次元モデルで は再現できないことに起因していると考えられる15).

\section{（3）初期洗掘過程の比較と考察}

実験室規模での堰下流部の洗掘現象は，潜り噴流時に 短時間で急激な洗掘が生じることが特徴である。そこで， 本研究では図-6に示す潜り噴流状態から，波状跳水に移 行するまでの初期洗掘過程について検討を行った. 図-7 

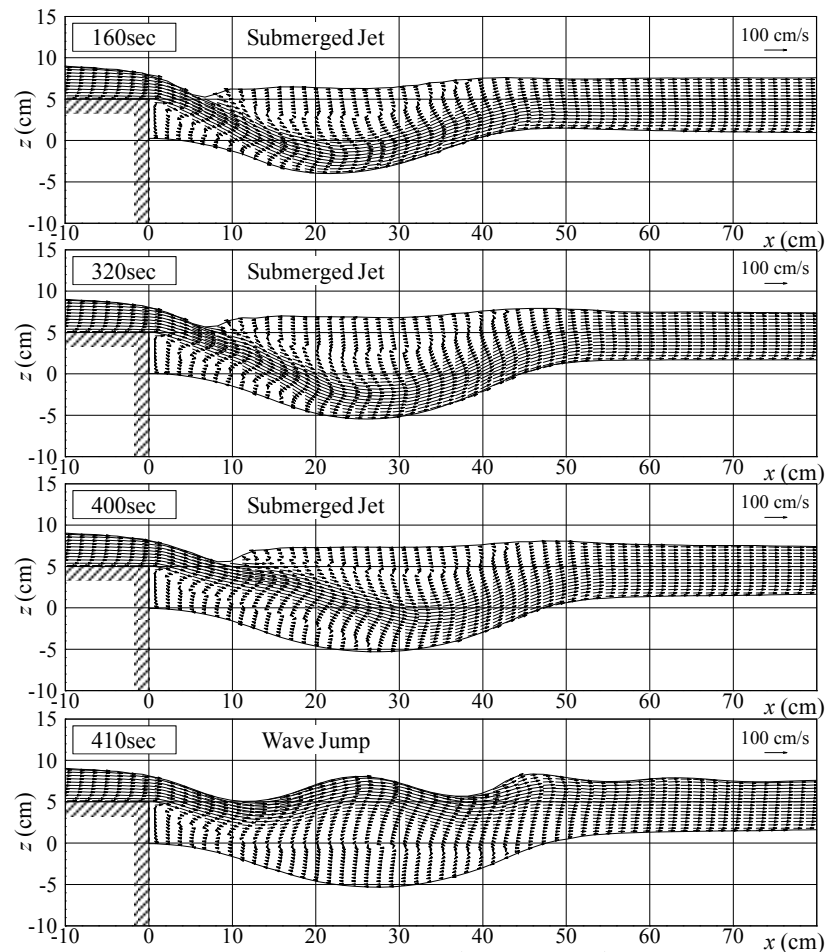

図-7 非平衡流砂モデル (NEモデル)

〜図-9に非平衡流砂モデル(NE)，平衡流砂モデル(EQ)お よびDEMモデルによる初期洗掘過程をそれぞれ示す.

まず，DEMモデルに関し，他のモデル同様，堰直下の 局所洗掘現象を表現できていることが分かる．各結果を 比較すると, NEモデルでは洗掘孔下流域に薄く土砂が 堆積しているのに対し, 他のモデルでは洗掘孔直下から 土砂の堆積が進行している．特に，EQモデルではその 傾向が著しい．図-10は，実験5および計算による初期洗 掘過程終了時の洗掘孔形状を, 各結果による最大洗掘深 $z_{\max }$ で無次元化表示したものである. 図より，実験結果 は計算と比較して，より局所的に洗掘孔が形成されてい る。これは，粒径の違いもあろうが，先述の様に，計算 では堰下流域での主流速の減少を再現できていないため, 洗掘孔が下流へ拡大したものと考えられる。，一方，計算 による洗掘孔形状は全モデルとも概ね一致している。し かし，洗掘孔下流の堆積高は，EQモデルでは実験結果 とほぼ同程度であるのに対し，NEモデルはかなり小さ い.DEMモデルでは洗掘孔下流に堆積が確認できるが, 実験およびEQモデルに比べ，緩やかな堆積形状となっ ている. 従来，2次元DEMでは安息角を十分再現できな いとされており9),19，粒子の回転運動に対して何らかの 抵抗を導入する必要性が指摘されている. 本モデルでは そのような抵抗は導入しておらず，土砂堆積形状につい ては十分再現できなかったものと考えられる.

最後に，洗掘速度について検討寸る．図-11は，最大 洗掘深の時間的変化を示したものである. 図より，NE モデルは実験結果および他のモデルに比べて非常に緩や かに洗掘が進行し， $5.5 \mathrm{~cm}$ の洗掘深に達した後に波状跳 水へと移行している. 音田ら ${ }^{11)}$ による水制周辺の局所洗 掘解析でも, NEモデルでは洗掘速度が遅い結果を得て
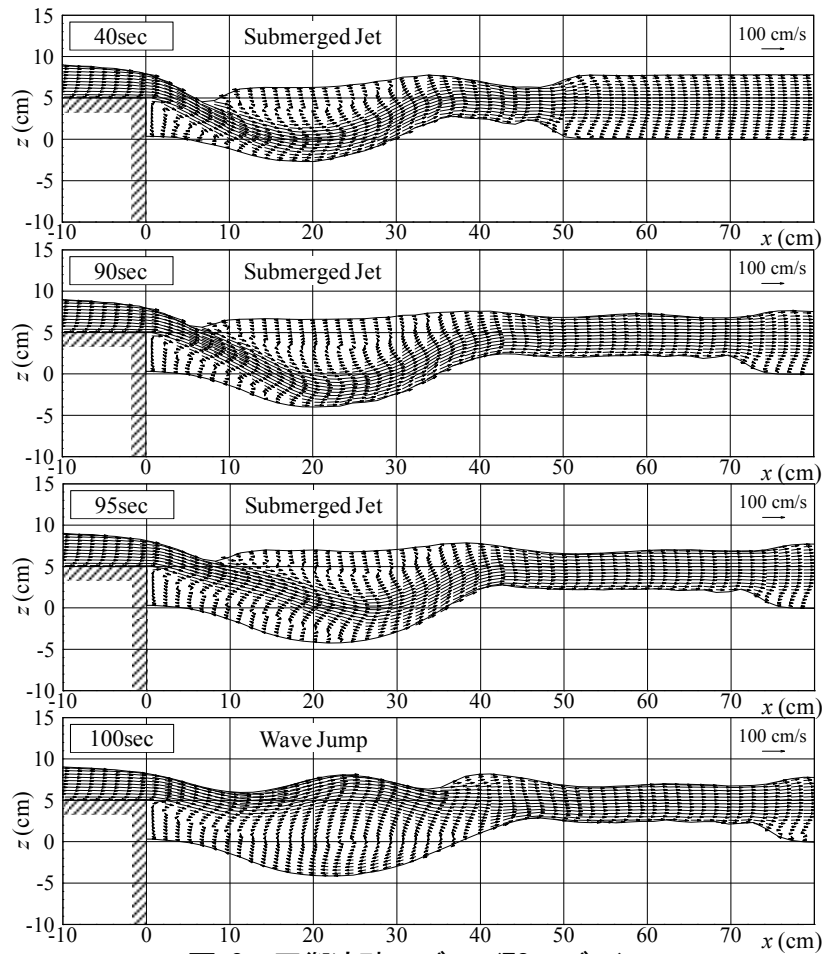

図-8＼cjkstart平衡流砂モデル（EQモデル）
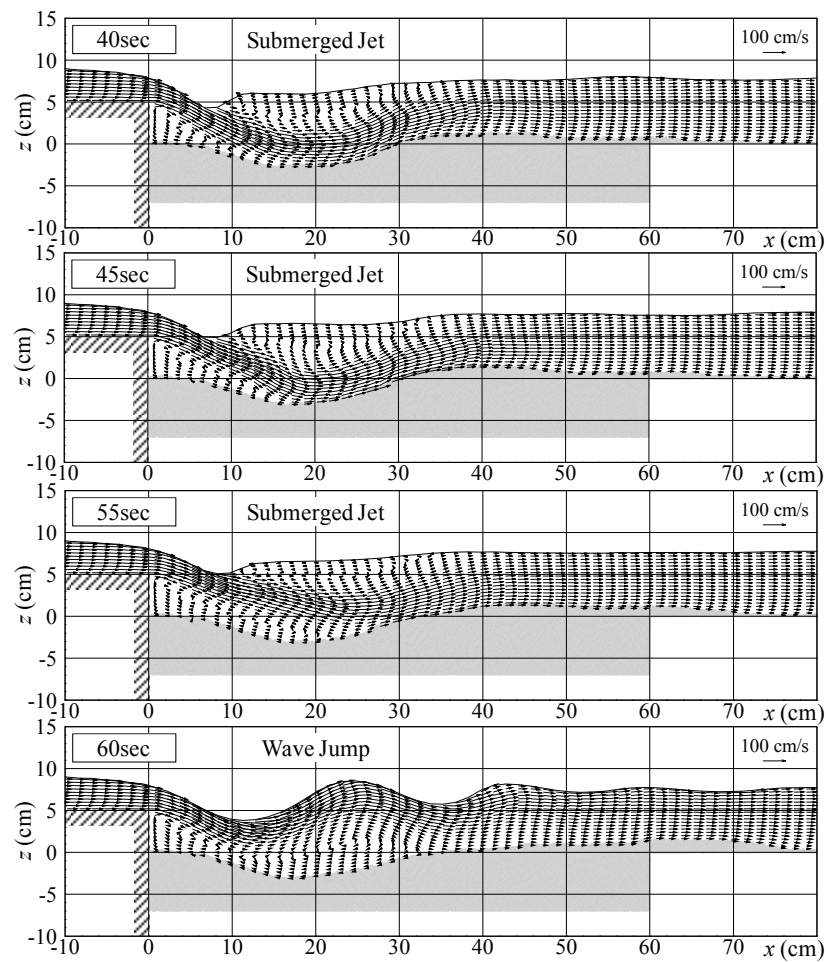

図-9 DEMモデル

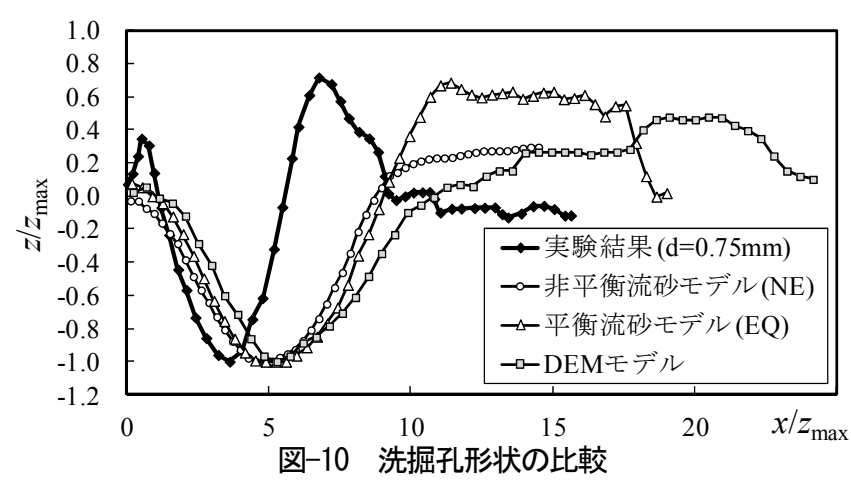




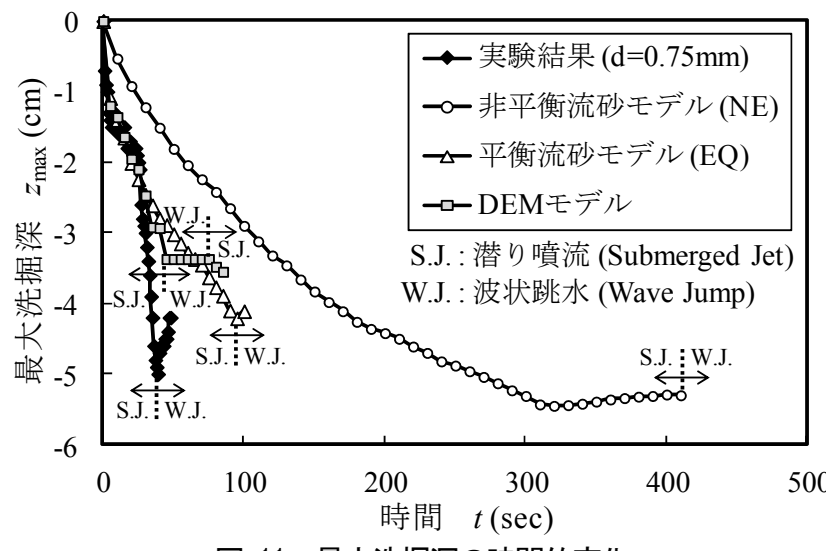

図-11 最大洗掘深の時間的変化

いる，一方，EQおよびDEMモデルでは，実験とは粒径 が異なるため一概には比較できないものの, 実験同様, 初期から急激に洗掘が進行し，その洗掘速度はほぼ同程 度であることが分かる，詳細に見ると，DEMモデルの 方が僅かながら洗掘速度が大きく, 実験結果に近い.さ らに，DEMモデルでは波状跳水状態から再度潜り噴流 へと移行し, 洗掘が進行している. 本計算条件での砂粒 径は $d=1.5 \mathrm{~mm}$ と比較的粗く, 最大無次元掃流力は 0.15 程 度であった，そのため，実験の様に流砂が大きく巻き上 がるような現象は起こらず，EQモデル，DEMモデルと もほぼ同一の洗掘過程になったと考えられる.

以上，本計算条件下では，DEMの導入による潜り噴 流時の流砂の巻き上がり現象までは再現できなかった.

しかし，洗掘孔形状，特に堆積形状については粒子の回 転運動に抵抗を導入することで再現できる可能性があり， また，洗掘速度については最も実験值に近い結果を得る ことができた．従って，DEMによる堰下流部の局所洗 掘現象の再現は十分可能であると考えられ，実験5) と同 様の砂粒子径を用いることにより，流砂の巻き上がりも 再現可能であると考えられる。一方，潜り噴流時の急激 な洗掘過程を考慮すると, 本研究による非平衡流砂モデ ルでは何らかの改良を施さない限り，堰下流部における 局所洗掘解析には適さないものと考えられる.

\section{5. おわりに}

本研究では，DEMを用いた河床変動モデルを構築し， 堰直下で発生する局所洗掘現象を対象として, 平衡・非 平衡流砂モデルおよびDEMによる河床変動解析を試み た. 以下に，本研究で得られた主要な結果を述べる.

(1) 本研究で構築したDEMによる河床変動モデルと, 既 往流砂量式とが一致することを示した，また，堰下 流部の局所洗掘現象にも適用できる可能性を示した.

(2) 本研究の計算条件下では，平衡流砂モデルおよびDE Mモデルによる洗掘速度は同程度であった。詳細に は，DEMモデルの方が若干洗掘速度が大きくなった。 (3) 本研究による非平衡流砂モデルでは, 洗掘速度がか
なり遅いことが明らかとなった，潜り噴流時の急激 な洗掘状況を再現するためには，本非平衡流砂モデ ルに何らかの改良を施す必要性を指摘した。

以上のことが明らかにされたが，今後は，潜り噴流時 に流砂が巻き上がるような実験条件下5)での検討を行う とともに，流砂量式にも言及していきたいと考えている.

\section{参考文献}

1) 鈴木幸一, 道上正規, 川津幸治 : 床固め直下流部の流れと 局所洗掘について, 第26回水理講演会論文集, pp.75-80, 1982.

2) Peter J. M. and Kanapathypilly A.: Free jet scour below dams and flip buckets, J. Hydr. Eng., ASCE, Vol.111, No.2, pp.220-235, 1985.

3) 神田佳一, 村本嘉雄, 藤田裕一郎 : 護床工下流部における 局所洗掘とその軽減法に関寸る研究, 土木学会論文集, No.551, pp.21-36, 1996.

4) 内田龍彦, 福岡捷二, 渡辺明英 : 床止め工下流部の局所洗 掘の数值解析モデルの開発，土木学会論文集，No.768/II-68， pp.45-54, 2004.

5) 梶川勇樹, 道上正規, 檜谷治, 中村真郷 : 常射流混在場に おける段落ち下流部の局所洗掘現象に関する数值計算, 水 工学論文集, 第49巻, pp.775-780, 2005.

6) 後藤仁志, 酒井哲郎 : 表層せん断を受ける砂層の動的挙動 の数值解析, 土木学会論文集, No.521/II-32, pp.101-112, 1995.

7) 後藤仁志, 原田英治, 酒井哲郎 : 個別要素法に基づく移動 床シミュレーターのモデル定数の最適化，土木学会論文集, No.691/II-57, pp.159-164, 2001.

8) 清水義彦, 若井明彦, 長田健吾 : 個別要素法と流れの数值 解析を組み合わせた高濃度平衡流砂場の数值実験, 水工学 論文集，第47巻，pp.559-564， 2003.

9) 笠原孟, 清水康行, 木村一郎, 山口里美 : DEM-URANS カップリングアプローチによるDune発生過程の数值シミュ レーション，水工学論文集，第55巻，pp.835-840, 2011.

10) Golparvar F. M., Yeganeh-Bakhtiary A. and Cheng L.: Twophase flow modeling of clear-water onset and jet scour under offshore pipelines, Proc., XXXI Int. Ass. Hydr. Eng. Res. Cong., Nov. 2005.

11) 音田慎一郎, 細田尚, 木村一郎, 岩田道明 : 平衡 - 非平衡 流砂モデルによる水制周辺の局所洗掘に関する数值解析, 水工学論文集, 第51巻, pp.943-948, 2007.

12) 木村一郎, 細田尚 : 乱れ強さ非負条件を考慮した非線形 $k-\varepsilon$ モデルによる立方体周辺流れの三次元解析, 水工学論文集, 第44巻, pp.599-604, 2000.

13) 中川博次, 辻本哲郎, 村上正吾 : 側岸における非平衡流砂 過程，第29回水理講演会論文集，pp.561-566, 1985.

14) Einstein, H. A.: The bed load function for sediment transportation in open channel flows, Technical Bulletin, No.1026, U.S. Dept. of Agriculture, Soil Conservation Service, 1950.

15) Kajikawa, Y. and Hinokidani, O.: 3D Numerical Simulation of Complex Flow over a Weir, 33rd IAHR Congress Proceedings, pp.2230-2237, 2009.

16) 長田健吾, 清水義彦, 若井明彦: 個別要素法を用いた流砂 解析における問題点に関する考察, 応用力学論文集, vol.7, pp.1033-1041, 2004.

(2011. 9. 30受付) 